\title{
Parasite-specific IgA response in infected children by Giardia intestinalis from rural communities of Venezuela.
}

\author{
Inés Duran ${ }^{1,2}$, Juan C. Jiménez ${ }^{*}$, Leonor Pocaterra ${ }^{3}$, Elsy Rojas ${ }^{3}$, GladymarPérez $^{3}$, Aurora Hernán ${ }^{3}$, Luz Núñez \\ ${ }^{1}$ Instituto de Inmunología, Caracas 1053, Capital District, Venezuela \\ ${ }^{2}$ Facultad de Medicina, Universidad Central de Venezuela, Caracas, Venezuela \\ ${ }^{3}$ Cátedra de Parasitología Escuela de Medicina, Venezuela
}

\begin{abstract}
Giardiasis is an infection caused by Giardia intestinalis into the small intestine that affects children in school age. The aim of the work was evaluated the specific $\operatorname{IgA}$ anti-Giardia antibodies in serum of children from rural communities were evaluated 100 children of 3 to 13 years old and measurement the levels of $\mathbf{I g A}$ antibody response against immunodominant antigens of Giardia intestinalis by ELISA and Westernblot. The soluble extract of Giardia intestinalis and fractions were obtained by differential centrifugation. Electrophoretic pattern showed several proteins from 205 to $14 \mathrm{kDa}$, and sera of infected children recognized proteins of 205,176 , a region from 76 to $41 \mathrm{kDa}$, and a band of $23 \mathrm{kDa}$ in the fraction 2 . The IgA antibody response anti-Giardia for to soluble extract was higher in infected children compared to uninfected children $(0.29 \pm 0.16$ vs. $0.07 \pm 0.04 ; p \leq 0.05)$. The IgA antibody response against the fraction 2 was higher in infected group than controls $(1.0 \pm 0.2 v s .0 .75 \pm 0.26 ; p \geq 0.05)$, the fraction 3 showed similar response to the soluble extract $(0.45 \pm 0.12$ vs. $0.3 \pm 0.12 ; p \geq 0.05)$. The infection by Giardia intestinalis produce specific IgA antibodies directed to the proteins of the fraction 2 . These proteins could be tested as antigens for serological diagnosis of giardiasis.
\end{abstract}

Keywords: Giardia, IgA, Antibody, ELISA, Serum, Children.

Accepted on August 22, 2018

\section{Introduction}

Giardia intestinalis is a chronic and debilitating tropical infection that often leads to clinical manifestations, is caused by intestinal parasite Giardia intestinalis [1]. In the absence of any preventive vaccine and effective chemotherapy to eliminate the parasites 200 million people suffer from at least one form of the disease [2]. The existence of acquired immunity in human giardiasis has been reported [3]. Antibody and T cell responses in human giardiasis have been analyzed with a view to understanding their relevance to the development of protective immunity [4]. The role played by Giardia-specific antibodies in preventing the persistence of infection or the development of chronic disease manifestations is still not understood. In addition, early work in this area focused on antibody responses in infected individuals compared with subjects with no infection or subjects from areas of endemicity who have been exposed to parasites but do not display any patent infection, and findings suggested qualitative and quantitative differences in the production of specific antibody responses [5-7]. Individuals with active giardiasis display higher levels of specific IgG but lower levels of $\operatorname{IgM}$ than do subjects free of established infection, and raised levels of Giardia specific $\operatorname{IgG}$ and $\operatorname{IgA}$ have been correlated with the presence or absence of parasites [8,9]. These and other investigators have quantified the levels of IgG, IgM, and $\operatorname{IgE}$ responses to different antigens [10-12], but curiously, there have been fewer reports in the literature on the levels of IgA antibody responses in human giardiasis [13]. Investigations have indicated the protective role of the specific IgA antibodies $[14,15]$. In this work, we describe the results about specific IgA antibodies in children infected by $G$. intestinalis. Therefore, the measurement of specific $\operatorname{IgA}$ antibodies in human giardiasis is essential for the endemic control and seroprevalence studies in rural communities.

\section{Methods}

\section{Population}

Were evaluated 100 sera from children of both sex between 3 and 13 years of age, with and without giardiasis demonstrated by coproparasitological test. For each child were taken $5 \mathrm{ml}$ of venous blood for serum, with prior informed consent signed by parents or legal representant. The study was approved by the Bioethics Committee of the Institute of Immunology of the Central University of Venezuela.

\section{Coproparasitological study}

A fecal specimen was collected per individual for the detection of eggs, larvae and/or giardiasis by direct examination with saline, lugol, and other techniques, such as Kato, Baermann, Formol-Triton-Ether and agar [16]. The individuals were examined clinically for the presentation of acute or/and chronic disease manifestations of Giardiasis by means of a proforma.

\section{Culture of the parasite and soluble extract preparation}

The trophozoites of Giardia intestinalis from an international reference strain WB (ATCC, 30957) was cultured in vitro in TYI-S-33 medium for 48 to $72 \mathrm{~h}$ at $37^{\circ} \mathrm{C}$ [17]. The parasites were washed in phosphate buffered saline (PBS) three times and lysed in $1 \mathrm{ml}$ of PBS in $0.2 \%$ Triton $\mathrm{X}-100$. The whole extract 
Citation: Duran I, Jiménez JC, Pocaterra L, et al. Parasite-specific IgA response in infected children by Giardia intestinalis from rural communities of Venezuela. J Parasit Dis Diagn Ther. 2018;3(2):11-17. DOI: 10.4066/2591-7846.1000028

was centrifuged at $1.680 \mathrm{x}$ for $5 \mathrm{~min}$ at $4^{\circ} \mathrm{C}$, recovering the supernatant as soluble extract.

\section{Fractions of Giardia intestinalis by differential centrifugation}

The fractions were obtained from soluble extract by centrifugation at $252 \mathrm{x} \mathrm{g}$ for $5 \mathrm{~min}$ at $4^{\circ} \mathrm{C}$ for the first sediment (Fraction 1). The supernatant was centrifuged again at $504 \mathrm{x}$ $\mathrm{g}$ for $5 \mathrm{~min}$ at $4^{\circ} \mathrm{C}$ for the second sediment (Fraction 2). The supernatant was centrifuged the third time at $1,680 \mathrm{x}$ for $10 \mathrm{~min}$ at $4^{\circ} \mathrm{C}$ for the sediment 3 (Fraction 3). Finally, the supernatant was centrifuged at $2,352 \times \mathrm{g}$ for 10 minutes at $4^{\circ} \mathrm{C}$ to obtain the fourth sediment (Fraction 4). All fractions were solubilized with $200 \mu \mathrm{L}$ of Tris- $\mathrm{HCl}, \mathrm{pH} 8.0$, Triton $\mathrm{X}-1000.2 \%$ and stored at $-80^{\circ} \mathrm{C}$ until use. The total protein concentration was determined by Lowry (1951) [18].

\section{Analysis of soluble extract and fractions of Giardia intestinalis by electrophoresis on polyacrylamide gels}

The soluble extract and fractions were analyzed by electrophoresis at $10 \%$ polyacrylamide gels [19]. The proteins were separated at 120 volts at room temperature. The gels were stained with silver and/or transferred to nitrocellulose membranes according to Towbin (1979) [20].

\section{Serological reactivity for IgA antibody response to soluble extract and fractions of $G$. intestinalis by Western blot}

The proteins of soluble extract and fractions were transferred to nitrocellulose membranes and were blocked with PBS-1\% skim milk for $1 \mathrm{hr}$ at room temperature. Subsequently, membranes were washed once with $0.05 \%$ PBS-Tween-20 for $10 \mathrm{~min}$ and incubated with sera from infected children with $G$. intestinalis or uninfected, diluted 1:50 with $0.05 \%$ PBS-Tween 20 overnight at $4^{\circ} \mathrm{C}$. The membranes were washed three times with PBSTween-20 $0.05 \%$ for $10 \mathrm{~min}$ and incubated with peroxidasecoupled anti-human IgA (chain- $\alpha$ ) secondary antibody (SIGMA ALDRICH) diluted at 1:750 in PBS-Tween $200.05 \%$ for 1 $\mathrm{hr}$ at room temperature. After washing, the membranes were revealed with 3,3',5,5'-Tetramethylbenzidine (TMB, Vector). Finally, photographed and digitized for analysis.

\section{Evaluation of the levels of IgA antibodies against soluble extract and fractions of G. intestinalis by ELISA}

Soluble extract, fraction 2 and fraction 3 of $G$. intestinalis were coupled in 96-well plates at a concentration of $10 \mu \mathrm{g} / \mathrm{well}$ in PBS pH 7.2 for $1 \mathrm{~h}$ at $37^{\circ} \mathrm{C}$ and overnight at $4^{\circ} \mathrm{C}$. Plates were washed once with PBS-T20 and blocked in PBS-T20 with $2 \%$ skim milk for $1 \mathrm{~h}$ at $37^{\circ} \mathrm{C}$. One-hundred $\mu \mathrm{l} /$ well of the individual sera of infected or uninfected children, diluted $1: 50$ in $0.1 \%$ PBS-T20 and $1 \%$ skim milk were incubated for $1 \mathrm{~h}$ at $37^{\circ} \mathrm{C}$ and then at $4^{\circ} \mathrm{C}$ overnight. The plates were washed three times with $0.1 \%$ PBS-T20 and incubated with $100 \mu \mathrm{l} /$ well of peroxidase coupled anti-human IgA ( $\alpha$-chain, SIGMA ALDRICH) diluted at $1: 1000$ in PBS-T20 at $0.1 \%$ for $1 \mathrm{~h}$ at $37^{\circ} \mathrm{C}$. Finally, the plates were washed and revealed with TMB $100 \mu \mathrm{L} /$ well. The reaction was stopped after 30 min with $50 \mu \mathrm{l}$ of $2 \mathrm{~N} \mathrm{H}_{2} \mathrm{SO}_{4}$ and the plate was read at $450 \mathrm{~nm}$ in ELISA reader (SUNRISE). The cut-off point was determined from the mean of optical densities (OD) of 20 uninfected individuals plus or minus 2 times the standard deviation.

\section{Statistical Analysis}

The data was analyzed by calculating the arithmetic mean and the standard deviation. The comparison of the means of the optical densities between the groups was evaluated by Student's $\mathrm{t}$ test, the value of $p \leq 0.05$ with statistical significance. The Med Calc Statistical Software Program was used 9.3.0.0.

\section{Results}

The electrophoretic profile of the soluble extract and fractions of G. intestinalis showed proteins from 205 to $14 \mathrm{kDa}$ of molecular weights (Figure 1). The most prominent proteins for the soluble extracts and fractions were those of $205,176,110,76,41$, and $23 \mathrm{kDa}$ respectively (Figure 1). When the pool of sera of infected individuals were tested for IgA antibodies in the soluble extract were recognized proteins of $205,176,110,76$, and $41 \mathrm{kDa}$ for the fraction F2 (Figure 2A). Sera of non-infected children did not react with any protein in the soluble extract or fractions (Figure 2B). A second pool of sera of infected individuals different from the first group reacted with proteins of $205,176,41$, and $30 \mathrm{kDa}$ in the soluble extract and a strong reaction for a protein of $23 \mathrm{kDa}$ in the fraction 2 (Figure 2C). Proteins of the soluble extract and the fractions $1,2,3$ and 4 were not recognized by serum of non-infected children (Figure 2D).

\section{Levels of IgA anti-Giardia against the soluble extract of $G$. intestinalis by ELISA}

The Figure 3 shows the mean of the optical density values (O.D.) in the group of infected individuals by G. intestinalis and not infected for specific IgA antibody response against soluble extract by ELISA. The higher level of antibodies was observed in the infected children compared to uninfected children $(0.29 \pm 0.16 v s$. $0.07 \pm 0.04, p \leq 0.05)$. The cut-off was $0.14 \pm 0.04$ according to the mean value in uninfected individuals (Figure 3).

\section{Levels of IgA anti-Giardia against the fractions of $G$. intestinalis by ELISA}

The Figure 4 shows the levels of specific IgA anti-Giardia response for soluble extracts, fraction 2 and the fraction 3 in the serum of infected and uninfected children. The higher levels of IgA anti-Giardia antibody response was observed inthe fraction 2 when was compared to the soluble extract andthe fraction 3 with statistical significance (Figure 4). In the case of the fraction

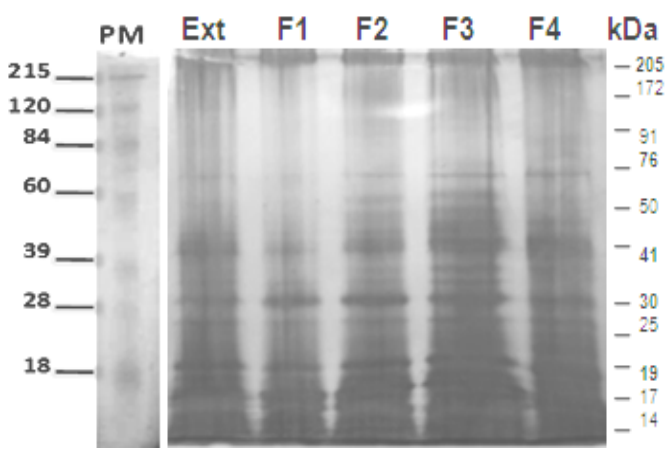

Figure 1. Electrophoretic profile by SDS-PAGE of soluble extracts (ext) and the fractions $(F)$ of $G$. intestinalis by differential centrifugation. To the left molecular pattern PM, F1 fraction 1, F2 fraction 2, F3 fraction 3 and F4 fraction 4. The visible proteins of the extracts and fractions after silver stain were those of 205 and $14 \mathrm{kda}$. 
2, did not show statistically significant differences of antibody levels among infected and non-infected children (1.02 $\pm 0.20 \mathrm{vs}$. $0.75 \pm 0.26 ; p \geq 0.05)$. The fraction 3 showed similar behavior when was compared to the soluble extract $(0.45 \pm 0.12$ vs. 0.29 $\pm 0.16 ; p \geq 0.05)$, but in both cases the response was greater in the infected than non-infected children.

\section{Discussion}

Giardiasis is an important problem of public health in worldwide with high morbidity caused by this parasite [21]. It is estimated in more than $30 \%$ of cases of diarrhea are caused by intestinal parasites, where the infection by Giardia intestinalis is the

A

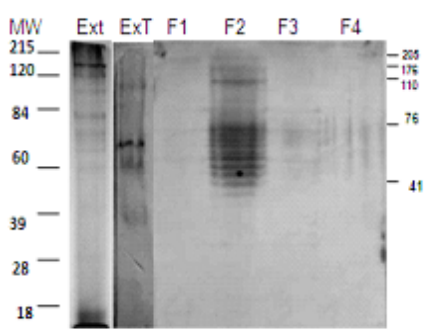

c

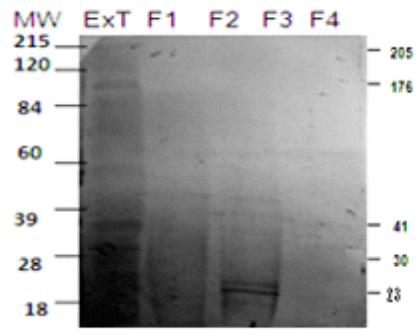

Figure 2. Reactivity of the anti-IgA antibodies against soluble extracts $($ Ext) and fractions $(F)$ of $G$. intestinalis in infected and non-infected children. (A) Western blotting of $G$. intestinal trophozoite lysates of polled serum of infected children recognized proteins of 205 to $41 \mathrm{kDa}$ in the fraction 2, $(B)$. A second group of serum showing reactivity for a 23-kDa protein in positive serum $(C)$, and polled serum of non-infected children (D).

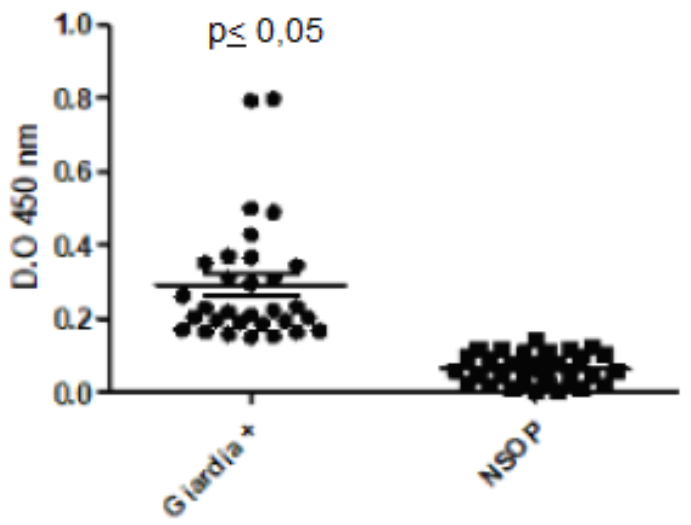

Figure 3. Levels of IgA-Giardia antibodies against proteins of soluble extracts in sera of infected children or non-infected children for $G$.

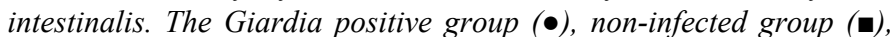
${ }^{*} p \leq 0.05$

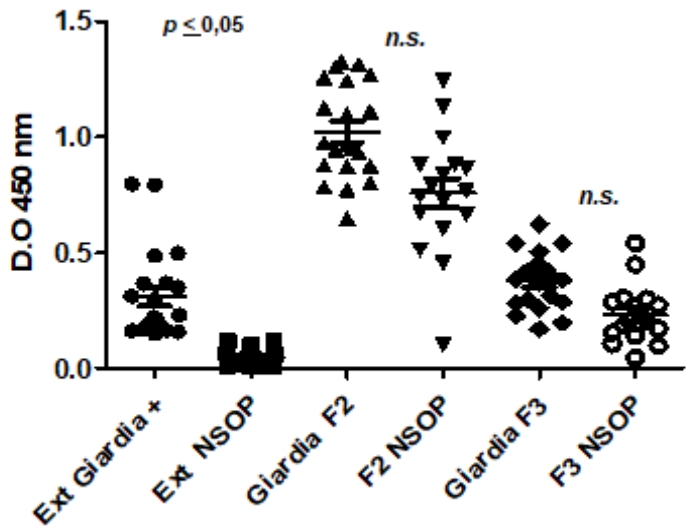

Figure 4. Levels of IgA antibodies to soluble extract and fractions 2 and 3 of G. duodenalisin serum of infected and non-infected children by G. intestinalis. Ext Giardia infected group (•), Ext NSOP non-infected

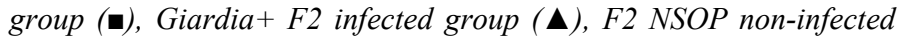
group $(\boldsymbol{\nabla})$, Giardia + F3 infected group ( $(\downarrow)$, and F3 NSOP non-infected group (o) respectively. ${ }^{*} p \leq 0,05$.

most reported [22]. The immunoglobulin A is the key antibody for intestinal infection control and parasite clearance [23]. Therefore, the identification of antigens related with the specific $\operatorname{IgA}$ antibody response is essential for diagnosis and possible vaccine [24]. The electrophoretic analysis of soluble extract and fractions of trophozoites of Giardia intestinalis showed proteins with molecular weights between 205 and $14 \mathrm{kDa}$. The most prominent proteins were of 205, 190, 176, 76, 41, 30 and $23 \mathrm{kDa}$. Previously, Soliman et al. identified at least eleven proteins with molecular weights of 170 to $31 \mathrm{kDa}$ respectively [10]. Also, Guimarães et al. determined by electrophoretic profile a fraction of Brazilian isolates, reporting the presence of 16 bands with molecular weights between 122 and $10 \mathrm{kDa}$ [11]. More recently, our group identified in the soluble extract bands between 137 and $14 \mathrm{kDa}$ reacting with the specific $\operatorname{IgA}$ antiGiardia in the serum of infected children [13]. In the present work, were detected new proteins for specific IgA antibody response against $G$. intestinalis antigens in the fractions with reactivity for proteins of $205,176,110 \mathrm{kDa}$, a region between 76 to $41 \mathrm{kDa}$ and the band of $23 \mathrm{kDa}$ which were mainly recognized in the fraction 2 . The protein of $41 \mathrm{kDa}$ could belong to $\alpha$ or $\beta$-tubulin, proteins present in the cytoskeleton and the flagella on the parasite M [25]. Other proteins have also been identified by proteomics studies similar to those detected in the present work such as the proteins of 65 to $80 \mathrm{kDa}[26,27]$. Therefore, the identification of these antigens is essential for evaluate the seroprevalence in endemic areas and serological diagnosis. The levels of IgA antibody against soluble extract were significantly higher in children infected with $G$. intestinalis compared to those not infected, confirming that the infection induce production of specific IgA anti-Giardia. Additionally, the sex distribution and age as risk factors were associated with the seroprevalence for IgA anti-Giardia. Therefore, the fractions were used as source of antigens for evaluate the specific response for anti-Giardia IgA by ELISA. Higher value of O.D. values in the fraction 2 than soluble extracts in serum of infected children was observed. This result indicates that the use of fractions improve the reactivity in the immunogenic antigens for measurement of specific IgA as an indicator of active infection than the study of 
IgG response, since giardiasis is a non-inflammatory infection and the immunoglobulin $\mathrm{A}$ is the predominant antibody in the gastrointestinal tract. Therefore, the evaluation of proteins presents in the fraction 2 as candidate for the design of sensitive immunological test to complement the coproparasitological diagnosis of one of the most frequent parasites in Venezuelan children will be our next step.

\section{Acknowledgement}

To the rural communities of Miranda State. Work was funded by the Project Science Mission 2007001425 and the Ministry of Science, Technology and Innovation Locti 2007, U.C.V.

\section{References}

1. Gilman RH, Brown KH, Visvesvara GS, et al. Epidemiology and serology of Giardia lamblia in a developing country: Bangladesh. Trans R Soc Trop Med Hyg. 1985;79(4):469-73.

2. World Health Organization. The World Health Report 1996. Fighting disease fostering development. Geneva: World Health Organization, 1996.

3. Faubert G. Immune response to Giardia duodenalis. Clin Microbiol Rev. 2000;13(1):35-54.

4. López-Romero G, Quintero J, Astiazarán-García H, et al. Host defences against Giardia lamblia. Parasite Immunol. 2015;37(8):394-406.

5. Miller S, Rosario C, Rojas E, et al. Intestinal parasitic infection and associated symptoms in children attending day care centers in Trujillo, Venezuela. Trop Med Int Health. 2003;8(4):342-47.

6. Thompson R, Reynoldson J, Mendis A. Giardia and giardiasis. Adv Parasitol. 1993;3:71-160.

7. Rodríguez OL, Hagel I, GonzálezY, et al. Secretory IgA antibody responses in Venezuelan children infected with Giardia duodenalis. J Trop Pediatr. 2004;50(2):68-72.

8. Char S, Cevallos A, Yamson P, et al. Impaired IgA response to Giardia heat shock antigen in children with persistent diarrhoea and Giardiasis. Gut. 1993;34(1):38-40.

9. Rosales DM, Díaz J, Doña-Leyva A, et al. Secretory inmune response to membrane antigens during Giardia lamblia infections in humans. Infect Immun. 1998;66(2):756-59.

10. Soliman M, Taghi-Kilani R, Ahmed FA, et al. Comparison of serum antibody responses to Giardia lamblia of symptomatic and asymptomatic patients. Am J Trop Med. 1998;58(2):232-39.

11. Guimarães S, Sogayar M, Franco M. Analysis of proteins from membrane and soluble fractions of Giardia duodenalis trophozoites of two brazilian axenic strains. Rev Inst Med Trop Sao Paulo. 2002;44(5)239-44.

12. Tellez A, Winiecka-Krusnell J, Paniagua M, et al. Antibodies in mother's milk protects children against giardiasis. Scand J Infect Dis. 2003;35(5):322-25.

13. Jiménez JC, Pinon A, Dive D, et al. Antibody response in children infected with Giardia intestinalis before and after treatment with secnidazole. Am J Trop Med. 2009;80(1):11-5.
14. Heyworth MF. Immunological aspects of Giardia infections. Parasite. 2014;21:551-4.

15. Dann SM, Manthey CF, Le C, et al. IL-17A promotes protective IgA responses and expression of other potential effectors against the lumen-dwelling enteric parasite Giardia. Exp Parasitol. 2015;156:68-78.

16. Allen AV, Ridley DS. Further observations on the formolether concentration technique for faecal parasites. J Clin Pathol. 1970;23(6):545-46.

17. Keister DB. Axenic culture of Giardia lamblia in TYI-S-33 medium supplemented with bile. Trans R Soc Trop Med Hyg. 1983;77(4):487-8.

18. Lowry OH, Rosenbrough NJ, Farr AL, et al. Protein measurement with the Follin Phenol Reagent. J Biol Chem. 1951;193(1):265-75.

19. Laemmli. Cleavage of Structural Proteins during the Assembly of the Head of Bacteriophage T4. Nature. 1970;227(5259):680-85.

20. Towbin H, Staehelin T, Gordon J. Electrophoretic transfer of proteins from polyacrylatnide gels to nitrocellulose sheets: procedure and some applications. Proc Nat Acad Sci USA. 1979;76(9):4350-4.

21. El-Gebaly NS, Halawa EF, Moussa HM, et al. Saliva and sera IgA and IgG in Egyptian Giardia-infected children. Parasitol Res. 2012;111(2):571-5.

22. Daniela CL, Iamara DA, Leticia LT, et al. Proteomic analysis of the ventral disc of Giardia lamblia. BMC Research Notes. 2012;5:41.

23. Langford TD, Housley MP, Boes M, et al. Central importance of immunoglobulin A in host defense against Giardia spp. Infect Immun. 2002;70(1):11-8.

24. Quintero J, ValdezA, Samaniego B, et al. Isolation and partial characterization of an immunogenic antigen of Giardia lamblia. Parasitol Int. 2017;66(3):324-30.

25. Kim J, Shin MH, Song KJ, et al. Evaluation of alphatubulinas an antigenic and molecular probe to detect Giardia lamblia. Korean J Parasitol. 2009;47(3):287-91.

26. Palm JE, Weiland ME, Griffiths WJ, et al. Identification of immunoreactive proteins during acute human Giardiasis. J Infect Dis. 2003;187(12):1849-59.

27. Yu X, Abdullahi AY, Wu S, et al. Prokaryotic expression of $\alpha-13$ Giardin gene and its intracellular localization in Giardia lamblia. Biomed Res Int. 2017;2017:1603264.

\section{*Correspondence to:}

Juan C. Jiménez

Instituto de Inmunología

Universidad Central de Venezuela

Caracas 1053, Capital District, Venezuela

E-mail: jcjimenez488@hotmail.com 